"Ça c'est canon!... »

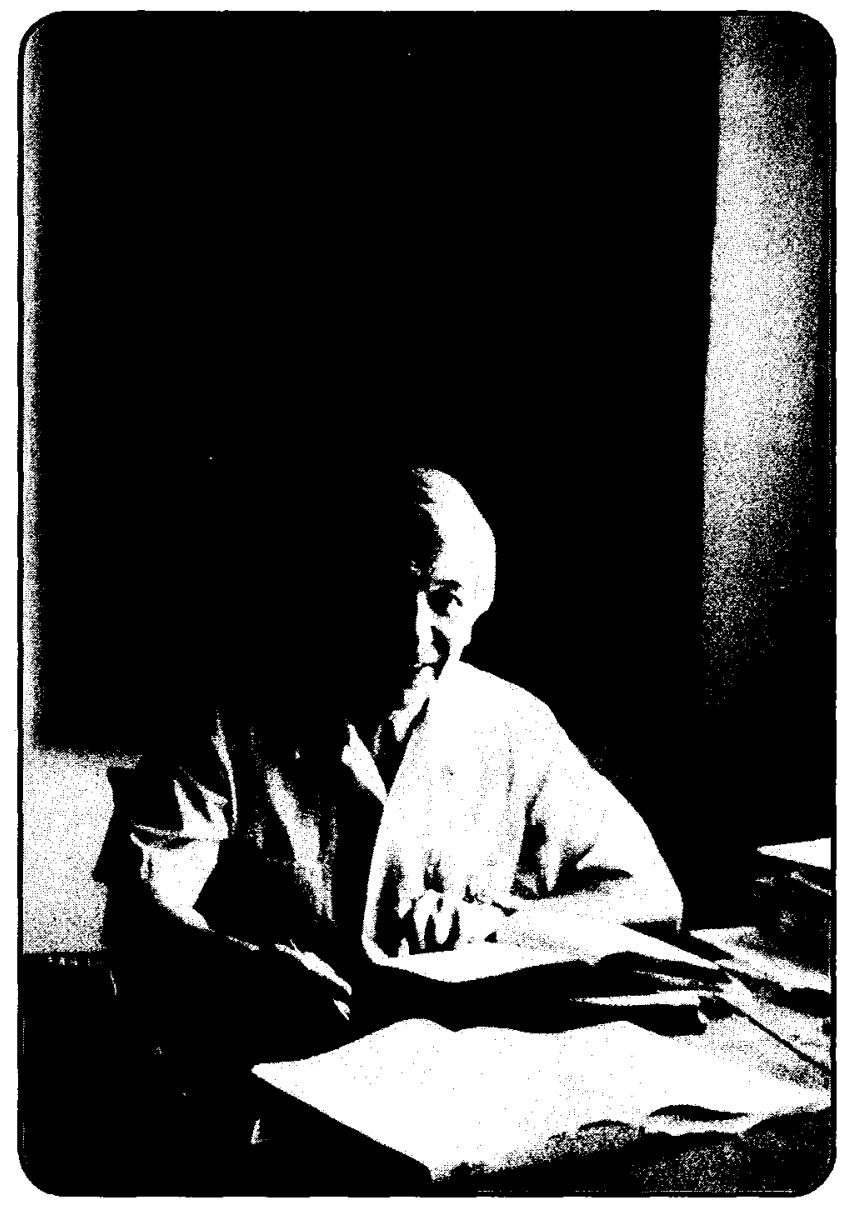

\title{
PIERRE LÉON
}

\section{Prix Rabelais (1994)}

Pour son roman Sur la piste des Jolicœur. Montréal : VLB éditeur, 1993. 